\title{
Lung volume and its subdivisions in normal and asthmatic males
}

\author{
MARGARET I. BLACKHALL and R. S. JONES \\ Institute of Child Health, University of Liverpool, Alder Hey Children's Hospital, Eaton Road, Liverpool 12
}

\begin{abstract}
Measurements of lung volume and its subdivisions were made in 89 asthmatic children and adults and 58 normal subjects. The asthmatics were divided into three groups according to the classification of Jones (1966). In this the $\mathrm{FEV}_{1}$ is used as an index of airways resistance which is divided into labile and fixed components. The compartment of lung volume showing the largest increase was the residual volume in subjects with a predominantly fixed increase of airways resistance (group 3) and this was true of both the children and adults. This compartment was also significantly enlarged in the labile subjects (groups 1 and 2). Significant increases in functional residual capacity were demonstrated in all three groups, especially in the children. Total lung capacity was significantly increased in the two labile groups of children but not in the adults. Even a low level of lability (group 1) may be associated with highly significant abnormalities in lung volume compartments which may be more evident in the child than in the adult.
\end{abstract}

There has been little attempt in the past to correlate the severity of asthma with change in lung volume and its subdivisions. Kraepelien, Engström, and Karlberg (1958) made measurements in children classified on clinical grounds as mild, moderate, and severe, and found functional residual capacity (FRC), residual volume (RV), and total lung capacity (TLC) to be significantly higher than normal. The most severe group showed the most marked changes, but since some children in each group gave normal values they considered that lung function and clinical classification do not always coincide.

Palmer and Diament (1969) studied lung volume and its compartments in adult asthmatics in acute attacks and found that severity correlated with degree of hyperinflation and that the best index of this is the ratio RV/TLC.

Changes in lung volume compartments clearly reflect changes in airway resistance. It has been shown that the latter is made up of fixed and labile components (Jones, 1966). The clinical presentation and course of the disease vary with the relative contributions of these components. Moreover, their relative importance changes with increasing age. The lung volume changes in childhood and adult asthma have therefore been examined in terms of a classification (Table I) based upon indices of labile and fixed components

1Correspondence to R. S. Jones
T A B LE I

CLASSIFICATION

\begin{tabular}{c|c|c}
\hline Group & Max. FEV & Lability $\%$ \\
\hline 1 & $\mathbf{N}$ & $15-30$ \\
2 & $<$ & $>30$ \\
3 & $\mathbf{N}$ & $\begin{array}{c}\text { Variable } \\
\mathbf{N}\end{array}$ \\
Normal & 20 \\
\hline
\end{tabular}

Lability index $=\frac{\text { Fall in } \mathrm{FEV}_{1} \text { (litres) }+ \text { rise of FEV } \text { (litres) }_{1}}{\text { Predicted normal FEV }_{1}} \times 100$ In the normal subject, the $F E V_{1}$ at rest replaces the predicted normal FEV .

Fall in $F_{1} V_{1}=$ fall from resting level after 8 minutes' exercise.

Rise in $\mathbf{F E V}_{1}=$ rise from resting level after bronchodilator drug + exercise for 1 minute.

Group 1: mild asthma, low lability index

Group 2: more severe asthma, high lability index

The arbitrary level separating groups 1 and 2 is $30 \%$ lability.

Group 3: lability varies, because of fixed component of airways resistance. Maximum FEV, (that is, after bronchodilator drug + exercise for 1 minute) below normal.

of airway resistance. In this paper asthma is defined as an abnormal degree of lability of the bronchial tree (lability index $>20 \%$ ) since this has proved to be more reliable that arbitrary clinical definitions in both the child and adult (Blackhall, 1970a; Blackhall, 1970b). Subjects with bronchitis were thus excluded by reason of a normal lability index.

The lability index and lung volume compartments were also measured in normal subjects since reports of the effect of age on TLC, RV, and FRC are somewhat conflicting. There is general agreement on the fact that RV increases with age. 
Kaltreider, Fray, and Hyde (1938) found a decrease with age in TLC and an increase in FRC. Needham, Rogan, and McDonald (1954) agreed that TLC decreased with age but found little alteration in FRC. Boren, Kory, and Syner (1966) found TLC and FRC to be correlated with height but unrelated to age, whereas RV correlated with both height and age; the correlation coefficient was, however, poor for all these.

In asthmatic subjects between attacks, Lukas (1951) found an increase in RV and Bates (1952) an increase in FRC in young subjects. Herschfus, Bresnick, and Segal (1953) found in adult subjects a reduced vital capacity and an increase in the ratio RV/TLC. Beale, Fowler, and Comroe (1952) reported an increase in FRC and RV but noted great variability.

\section{MATERIAL AND METHODS}

In the first instance, 58 normal and 89 asthmatic subjects were studied. These were divided into children aged 6 to 16 years, young adults aged 17 to 32 years, and older adults aged 33 to 53 years. The childhood group consisted of 19 normal subjects and 44 asthmatics; the young adult group was composed of 21 normal subjects and 34 asthmatics; while the older group contained 18 normals and 11 asthmatics.

SUBJECTS STUDIED Normal adults were members of the hospital staff-doctors, students, and laboratory technicians. Normal children were the sons of staff and their friends. They were accepted only if they were entirely free of respiratory symptoms and had no history suggestive of chronic respiratory disease. Although they were by no means a random sample of the population, the results obtained from the group were very similar to those found by other workers (Engström, Karlberg, and Kraepelien, 1956). Thus it was considered justifiable to use them as a control group and these data were used to predict normal values for the asthmatic subjects of comparable age. The lability indices were measured on all normal subjects and it will be seen (Table II) that the results are within normal limits.

T A B L E I I

LABILITY INDEX IN NORMAL CONTROLS

\begin{tabular}{|c|c|c|}
\hline \multirow{2}{*}{$\frac{\text { Age (yr) }}{8-16}$} & \multicolumn{2}{|c|}{ Lability Index $\%$} \\
\hline & $\begin{array}{l}\text { Mean } \\
\text { Range } \\
\text { SD }\end{array}$ & $\begin{array}{l}10 \cdot 3 \\
2-20 \\
5\end{array}$ \\
\hline $17-32$ & $\begin{array}{l}\text { Mean } \\
\text { Range } \\
\text { SD }\end{array}$ & $\begin{array}{l}9 \cdot 9 \\
5-19 \\
3 \cdot 5\end{array}$ \\
\hline $33-53$ & $\begin{array}{l}\text { Mean } \\
\text { Range } \\
\text { SD }\end{array}$ & $\begin{array}{l}8 \cdot 6 \\
3-19 \\
4\end{array}$ \\
\hline
\end{tabular}

Asthmatic subjects were chosen from those who had well-documented histories over long periods, so? that the severity of their asthma could be assessed음 with reasonable accuracy. In this way, subjects whon had been stable over a considerable number of years were obtained. Children with asthma formed a cross-0 section of those attending the asthma clinic at Alder Hey Children's Hospital. Since few children witho mild asthma are referred to the clinic, this group. was a small one. The majority of children attending the hospital belong to the moderately severe group and a smaller number to the severe group.

Adults with asthma from childhood came fromin three sources. The majority had attended the asthma clinic at one of the Liverpool City hospitals, ando case histories dating from childhood were available! Another group consisted of those who in childhoof had attended the asthma clinic at Alder Hey Child ren's Hospital. A few older subjects with asthmoर्क्य came from general practitioners.

METHODS The lability index (Jones, 1966) was used to classify the asthmatic patients into three groupso (Table I). This classification is based upon measure ments of lability made between attacks when the sub:ject is clinically 'well' and all measurements reporte here were made under these conditions. Group asthmatics are only a little more labile than the nor mal subjects. Group 2 are highly labile and in Groun: 3 , the fixed component of airways resistance (AR predominates. It should be noted that a high lability index is not synonymous with severe asthma; the subject may not have clinical asthma at all. It des cribes the degree to which the bronchioles constric and dilate in response to specific stimuli.

Since the results for normal subjects (Table III showed a definite effect of age on lung volume com은 partments, which became apparent in the group age产 17 to 32 years, a further 15 normal men were adde to this group so that the age effect could be studie $\Phi$. more accurately. The total of 36 subjects were theid divided into two groups aged 17 to 24 years ans 25 to 32 years, each containing 18 subjects.

Measurement of lung volume and its subdivision? was made with the subject in the sitting position and after resting for 15 minutes. The FRC was deter. mined by a closed-circuit helium dilution techniques (Gilson and Hugh Jones, 1949). Oxygen was fed in manually through a small rotameter to replace than being used by the patient, thus keeping the restine expiratory level constant. The oxygen content of the circuit gases was kept at approximately $21 \%$. Wher the subject had reached equilibrium with the mixtufe of air and helium in the spirometer, the expirator reserve volume (ERV) was measured, followed b. $y^{\prime}$ the inspiratory reserve volume (IRV). Two attempts at each were made and the larger figure for each was used in calculating the vital capacity (VC).

Duplicate estimations on 12 subjects gave a mea change between first and second estimations in FRe of $0.013 \pm 0.117$, in RV of $0.051 \pm 0.068$, and in TL of $0.035 \pm 0 \cdot 102$. All volumes were measured 
T A B LE I I I

\begin{tabular}{|c|c|c|c|c|}
\hline & Regression Equation & $\mathbf{R}$ & RSD & $\mathbf{F}$ \\
\hline $\begin{array}{l}\text { Children }(\mathrm{n}=19) \\
\text { Correlation with height } \\
\text { Correlation with height and age }\end{array}$ & $\begin{aligned} \mathbf{F R C} & =0.54 \times \mathrm{Ht}^{3}-0.19 \\
\mathbf{R V} & =0.21 \times \mathrm{Ht}^{3}-0.04 \\
\text { TLC } & =1.22 \times \mathrm{Ht}^{3}-0.24 \\
\text { FRC } & =0.37 \times \mathrm{Ht}^{3}+0.09 \times \mathrm{Age}-0.62 \\
\text { RV } & =0.15 \times \mathrm{Ht}^{3}+0.03 \times \mathrm{Age}-0.20 \\
\text { TLC } & =1.00 \times \mathrm{Ht}^{3}+0.12 \times \mathrm{Age}-0.83\end{aligned}$ & $\begin{array}{l}0.93 \\
0.94 \\
0.96 \\
0.94 \\
0.95 \\
0.97\end{array}$ & $\begin{array}{l}0 \cdot 32 \\
0 \cdot 11 \\
0 \cdot 51 \\
0 \cdot 30 \\
0 \cdot 11 \\
0 \cdot 50\end{array}$ & $\begin{array}{r}108 \cdot 19 \\
126 \cdot 58 \\
210 \cdot 16 \\
60 \cdot 97 \\
71 \cdot 83 \\
111 \cdot 96\end{array}$ \\
\hline $\begin{array}{l}\text { Adults } 17-24 \text { years }(\mathrm{n}=18) \\
\text { Correlation with height } \\
\text { Correlation with height and age }\end{array}$ & $\begin{aligned} F R C & =0.49 \times \mathrm{Ht}^{3}+0.45 \\
\mathbf{R V} & =0.28 \times \mathrm{Ht}^{3}-0.15 \\
\text { TLC } & =0.81 \times \mathrm{Ht}^{3}+2.37 \\
\text { FRC } & =0.46 \times \mathrm{Ht}^{3}-0.03 \times \text { Age }+1.31 \\
\text { RV } & =0.28 \times \mathrm{Ht}^{3}-0.0002 \times A g e-0.14 \\
\text { TLC } & =0.80 \times \mathrm{Ht}^{3}-0.02 \times \text { Age }+2.98\end{aligned}$ & $\begin{array}{l}0.65 \\
0.56 \\
0.60 \\
0.67 \\
0.56 \\
0.61\end{array}$ & $\begin{array}{l}0.34 \\
0 \cdot 25 \\
0 \cdot 64 \\
0 \cdot 35 \\
0 \cdot 26 \\
0.66\end{array}$ & $\begin{array}{r}11 \cdot 71 \\
7 \cdot 30 \\
9 \cdot 16 \\
5 \cdot 99 \\
3 \cdot 40 \\
4 \cdot 33\end{array}$ \\
\hline $\begin{array}{l}\text { Adults } 25-32 \text { years }(\mathrm{n}=18) \\
\text { Correlation with height } \\
\text { Correlation with height and age }\end{array}$ & $\begin{aligned} F R C & =0.68 \times \mathbf{H t}^{3}-0.65 \\
\mathbf{R V} & =0.38 \times \mathrm{Ht}^{3}-0.59 \\
\text { TLC } & =1.24 \times \mathrm{Ht}^{3}+0.14 \\
F R C & =0.64 \times \mathrm{Ht}^{3}+0.02 \times \mathrm{Age}-1.15 \\
\mathbf{R V} & =0.32 \times \mathrm{Ht}^{3}+0.03 \times \mathrm{Age}-1.30 \\
\text { TLC } & =1.10 \times \mathrm{Ht}^{3}+0.09 \times \mathrm{Age}-2.05\end{aligned}$ & $\begin{array}{l}0.66 \\
0.74 \\
0.74 \\
0.67 \\
0.77 \\
0.76\end{array}$ & $\begin{array}{l}0.51 \\
0.24 \\
0.80 \\
0.55 \\
0.18 \\
0.80\end{array}$ & $\begin{array}{r}12 \cdot 66 \\
19 \cdot 77 \\
19 \cdot 17 \\
6 \cdot 08 \\
11 \cdot 17 \\
10 \cdot 03\end{array}$ \\
\hline $\begin{array}{l}\text { Adults 33-53 years }(\mathrm{n}=18) \\
\text { Correlation with height } \\
\text { Correlation with height and age }\end{array}$ & $\begin{aligned} \mathbf{F R C} & =0.12 \times \mathrm{Ht}^{3}+2.27 \\
\text { RV } & =0.27 \times \mathrm{Ht}^{3}+0.11 \\
\text { TLC } & =0.73 \times \mathrm{Ht}^{3}+2.93 \\
\text { FRC } & =0.16 \times \mathrm{Ht}^{3}+0.04 \times \mathrm{Age}+0.33 \\
\mathbf{R V} & =0.31 \times \mathrm{Ht}^{3}+0.04 \times \mathrm{Age}-1.86 \\
\text { TLC } & =0.79 \times \mathrm{Ht}^{3}+0.07 \times \mathrm{Age}+0.13\end{aligned}$ & $\begin{array}{l}0.10 \\
0.37 \\
0.48 \\
0.45 \\
0.80 \\
0.72\end{array}$ & $\begin{array}{l}0.53 \\
0.33 \\
0.64 \\
0.52 \\
0.22 \\
0.52\end{array}$ & $\begin{array}{r}0 \cdot 18 \\
2 \cdot 56 \\
4 \cdot 89 \\
1 \cdot 88 \\
13 \cdot 73 \\
8 \cdot 17\end{array}$ \\
\hline
\end{tabular}

ambient temperature and pressure saturated (ATPS) and corrected to body temperature and pressure saturated (BTPS).

Linear regression equations were calculated relating the subdivision of lung volume and the cube of the height in metres. Multiple linear regression equations were also calculated, relating the same components to height cubed and the subject's age. The multiple correlation coefficient $(R)$ of the regression equation was tested for significance using the $F$ test and the residual standard deviation (RSD) was calculated. The significance of the differences between the mean values of pairs of groups was estimated using the modification of Student's $t$ test for examining unrelated pairs.

\section{RESULTS}

CORRELATION OF LUNG VOLUME COMPARTMENTS WITH AGE AND HEIGHT IN NORMAL SUBJECTS In the group of children an equally high degree of correlation is present when regression equations based on height alone or height and age are used (Table III). The expanded adult group of 36 subjects aged 17 to 32 years was subdivided into two subgroups. In the first, which consisted of 18 males aged 17 to 24 years, the significance of correlation with height was better than with height and age. In the older group of 18 subjects, aged 25 to 32 years, there was no difference between the height and the age correlations and in the older adults aged 33-53 years there was no correlation with height alone. Height is clearly of importance during the growth period whereas age, presumably because of associated degenerative changes, becomes important when growth ceases. Regression equations based upon height alone were therefore used to obtain predicted normal values for the group of asthmatic children, and height and age were used for the younger and older adult groups.

ASTHMATIC CHILDREN The mean values for asthmatic subjects and predicted normal values

T A B LE IV

RESULTS IN CHILDREN

\begin{tabular}{|c|c|c|c|c|}
\hline & Normal & $\begin{array}{l}\text { Group } 1 \\
\text { Asthma }\end{array}$ & $\begin{array}{l}\text { Group } 2 \\
\text { Asthma }\end{array}$ & $\begin{array}{c}\text { Group } 3 \\
\text { Asthma }\end{array}$ \\
\hline No. & 19 & 8 & 24 & 12 \\
\hline $\begin{array}{l}\text { Age (yr) } \\
\text { Mean } \\
\text { SD }\end{array}$ & $\begin{array}{c}11 \cdot 7 \\
2.97\end{array}$ & $\begin{array}{r}11.0 \\
1.9\end{array}$ & $\begin{array}{r}11 \cdot 3 \\
2 \cdot 7\end{array}$ & $\begin{array}{r}12 \cdot 3 \\
1 \cdot 5\end{array}$ \\
\hline $\begin{array}{l}\text { Height (metres) } \\
\text { Mean } \\
\text { SD }\end{array}$ & $\begin{array}{l}1.49 \\
0.21\end{array}$ & $\begin{array}{l}1.38 \\
0.09\end{array}$ & $\begin{array}{l}1 \cdot 39 \\
0 \cdot 11\end{array}$ & $\begin{array}{l}1.45 \\
0.09\end{array}$ \\
\hline $\begin{array}{l}\text { FRC (litres) } \\
\text { Mean } \\
\text { SD }\end{array}$ & $\begin{array}{l}1 \cdot 72 \\
0.81\end{array}$ & $\begin{array}{l}1.57(1.26) \\
0.32(0.27)\end{array}$ & $\begin{array}{l}1.68(1.30) \\
0.54(0.35)\end{array}$ & $\begin{array}{l}2.31(1.48) \\
0.47(0.43)\end{array}$ \\
\hline $\begin{array}{l}\text { RV (litres) } \\
\text { Mean } \\
\text { SD }\end{array}$ & $\begin{array}{l}0.71 \\
0.32\end{array}$ & $\begin{array}{l}0.78(0.51) \\
0.15(0.11)\end{array}$ & $\begin{array}{l}0.93(0.53) \\
0.38(0.14)\end{array}$ & $\begin{array}{l}1.60(0.60) \\
0.38(0.12)\end{array}$ \\
\hline $\begin{array}{l}\text { TLC (litres) } \\
\text { Mean } \\
\text { SD }\end{array}$ & $\begin{array}{l}4 \cdot 08 \\
1 \cdot 77\end{array}$ & $\begin{array}{l}3.33(3.01) \\
0.58(0.62)\end{array}$ & $\begin{array}{l}3.52(3.11) \\
0.89(0.79)\end{array}$ & $\begin{array}{l}3.90(3.51) \\
0.73(0.69)\end{array}$ \\
\hline
\end{tabular}

Predicted normal values in parentheses from regression equation on normal group 
are shown in Table IV. There is a significant increase in residual volume in groups 1,2 , and 3 , the means being 151,176 , and $266 \%$ respectively above the mean value for the normal group. Similarly, the FRC is significantly higher in each group, the means being increased by 125,129 , and $156 \%$. The TLC shows a smaller but again significant increase, the means being 111, 113, and $111 \%$ respectively above the normal values.

YOUNG ASTHMATIC ADULTS The largest increase is in the residual volume (Table V) which is significantly increased in all groups, the means being 140,142 , and $219 \%$ above the mean for the normal group. The FRC shows a less striking change, only groups 2 and 3 being significantly increased. The percentage increase in the mean

T A B L E V

RESULTS FOR ADULTS 17-32 YEARS

\begin{tabular}{|c|c|c|c|c|}
\hline & Normal & $\begin{array}{l}\text { Group } 1 \\
\text { Asthma }\end{array}$ & $\underset{\text { Asthma }}{\text { Group } 2}$ & $\begin{array}{l}\text { Group } 3 \\
\text { Asthma }\end{array}$ \\
\hline No. & 21 & 12 & 7 & 15 \\
\hline $\begin{array}{l}\text { Age (yr) } \\
\text { Mean } \\
\text { SD }\end{array}$ & $\begin{array}{r}26 \cdot 1 \\
5 \cdot 1\end{array}$ & $\begin{array}{r}25 \cdot 8 \\
4 \cdot 7\end{array}$ & $\begin{array}{r}20 \cdot 9 \\
3 \cdot 4\end{array}$ & $\begin{array}{r}24.5 \\
5.7\end{array}$ \\
\hline $\begin{array}{l}\text { Height (metres) } \\
\text { Mean } \\
\text { SD }\end{array}$ & $\begin{array}{l}1.76 \\
0.07\end{array}$ & $\begin{array}{l}1.76 \\
0.08\end{array}$ & $\begin{array}{l}1.71 \\
0.08\end{array}$ & $\begin{array}{l}1.67 \\
0.05\end{array}$ \\
\hline $\begin{array}{l}\text { FRC (litres) } \\
\text { Mean } \\
\text { SD }\end{array}$ & $\begin{array}{l}3 \cdot 11 \\
0.70\end{array}$ & $\begin{array}{l}3.53(3.23) \\
0.67(0.54)\end{array}$ & $\begin{array}{l}3.54(2.93) \\
0.70(0.43)\end{array}$ & $\begin{array}{l}3.78(2.63) \\
0.72(0.28)\end{array}$ \\
\hline $\begin{array}{l}\text { RV (litres) } \\
\text { Mean } \\
\text { SD }\end{array}$ & $\begin{array}{l}1.45 \\
0 \cdot 34\end{array}$ & $\begin{array}{l}1.95(1.39) \\
0.49(0.20)\end{array}$ & $\begin{array}{l}1.84(1.30) \\
0.48(0.15)\end{array}$ & $\begin{array}{l}2.58(1.18) \\
0.59(0.10)\end{array}$ \\
\hline $\begin{array}{l}\text { TLC (litres) } \\
\text { Mean } \\
\text { SD }\end{array}$ & $\begin{array}{l}7 \cdot 04 \\
1 \cdot 09\end{array}$ & $\begin{array}{l}7 \cdot 37(7 \cdot 15) \\
0.97(0.93)\end{array}$ & $\begin{array}{l}7 \cdot 12(6 \cdot 56) \\
1 \cdot 30(0 \cdot 78)\end{array}$ & $\begin{array}{l}6.47(6.15) \\
1.06(0.52)\end{array}$ \\
\hline
\end{tabular}

Predicted normal values in parentheses from regression equation on normal group
T A B L E V I

RESULTS FOR ADULTS 33-53 YEARS

\begin{tabular}{|c|c|c|}
\hline & Normal & Group 3 Asthma \\
\hline No. & 18 & 9 \\
\hline $\begin{array}{c}\text { Age }(y r) \\
\text { Mean } \\
\text { SD }\end{array}$ & $\begin{array}{c}33-53 \\
40 \cdot 8 \\
5 \cdot 5\end{array}$ & $\begin{array}{c}33-42 \\
37 \cdot 3 \\
3 \cdot 2\end{array}$ \\
\hline $\begin{array}{l}\text { Height (metres) } \\
\text { Mean } \\
\text { SD }\end{array}$ & $\begin{array}{l}1.74 \\
0.05\end{array}$ & $\begin{array}{l}1.72 \\
0.09\end{array}$ \\
\hline $\begin{array}{c}\text { FRC (litres) } \\
\text { Mean } \\
\text { SD }\end{array}$ & $\begin{array}{l}2.93 \\
0.54\end{array}$ & $\begin{array}{l}4.59(2.75) \\
2.75\end{array}$ \\
\hline $\begin{array}{l}\text { RV (litres) } \\
\text { Mean } \\
\text { SD }\end{array}$ & $\begin{array}{l}1 \cdot 55 \\
0 \cdot 33\end{array}$ & $\begin{array}{l}3.55(1.35) \\
0.75\end{array}$ \\
\hline $\begin{array}{l}\text { TLC (litres) } \\
\text { Mean } \\
\text { SD }\end{array}$ & $\begin{array}{l}6 \cdot 82 \\
0 \cdot 69\end{array}$ & $\begin{array}{l}7.53(6.42) \\
0.90\end{array}$ \\
\hline
\end{tabular}

Predicted normal values in parentheses from regression equations on normal group

values is 109,121 , and 144 respectively. The TLC did not change significantly.

OLDER ASTHMATIC ADULTS Nine of the 11 asth-言 matics were in group 3 , one in group 1 , and one in group 2 (Table VI). The predominance of group $\mathbb{Q}$ 3 reflects the tendency of this type of asthma to $\Rightarrow$ become relatively more common with age (Black-O hall, 1970a, b). The group 1 subject had an ob- $\frac{3}{5}$ served value of $3.67 \mathrm{l}$. for FRC (predicted $=$ ? 2.651 )., 2.07 1. for RV (predicted $=1.281$.), and 7.851 . for TLC (predicted $=6.39$ 1.). The group 2 今 subject had an FRC of 3.16 1. (predicted $=2.67$ 1.), an RV of 2.601 . (predicted $=1.341$.) and TLC of 6.701 . (predicted $=6.531$.).

The nine group 3 subjects showed a significanto increase in FRC, RV, and TLC, the mean values

T A B LE VII

SIGNIFICANCE OF RESULTS

\begin{tabular}{|c|c|c|c|c|c|c|c|}
\hline & & \multicolumn{2}{|c|}{ FRC } & \multicolumn{2}{|c|}{$\mathbf{R V}$} & \multicolumn{2}{|c|}{ TLC } \\
\hline & & Children & $\begin{array}{c}\text { Adults } \\
17-32\end{array}$ & Children & $\begin{array}{c}\text { Adults } \\
17-32\end{array}$ & Children & $\begin{array}{l}\text { Adults } \\
17-32\end{array}$ \\
\hline $\begin{array}{l}\text { Normal } v \\
\text { Group } 1\end{array}$ & $\begin{array}{l}t \\
\mathbf{P}\end{array}$ & $\begin{array}{r}4.07 \\
<0.001 \\
\end{array}$ & $0.2>P>0.1$ & $\begin{array}{c}5.97 \\
<0.001\end{array}$ & $\begin{array}{c}3.97 \\
<0.001\end{array}$ & $\begin{array}{r}3.08 \\
<0.01 \\
\end{array}$ & $\begin{array}{c}0.90 \\
0.2>P>0.1\end{array}$ \\
\hline $\begin{array}{l}\text { Normal } v \\
\text { Group } 2\end{array}$ & $\begin{array}{l}t \\
\mathbf{P}\end{array}$ & $\begin{array}{l}3.85 \\
<0.001 \\
\end{array}$ & $\begin{array}{r}2.78 \\
=0.01 \\
\end{array}$ & $\begin{aligned} & 5.05 \\
< & 0.001\end{aligned}$ & $\begin{array}{r}3.23 \\
<0.01\end{array}$ & $\begin{aligned} & 4.02 \\
< & 0.001\end{aligned}$ & $0.2>P>0.1$ \\
\hline $\begin{array}{l}\text { Normal } v \\
\text { Group } 3\end{array}$ & $\begin{array}{l}t \\
\mathbf{P}\end{array}$ & $\begin{array}{l}6 \cdot 12 \\
<0.001\end{array}$ & $\begin{array}{l}5.65 \\
<0.001\end{array}$ & $\begin{array}{l}9.13 \\
<0.001\end{array}$ & $\begin{array}{l}8.13 \\
<0.001\end{array}$ & $\begin{array}{c}2.56 \\
0.02>P>0.01\end{array}$ & $\begin{array}{c}1.18 \\
0.5>P>0.2\end{array}$ \\
\hline $\begin{array}{l}\text { Group } 1 v \\
\text { Group } 2\end{array}$ & $\begin{array}{l}t \\
\mathbf{P}\end{array}$ & $\begin{aligned} & 0.35 \\
> & 0.5\end{aligned}$ & $0.5>P>0.2$ & $\begin{array}{c}0.83 \\
0.5>P>0.2\end{array}$ & $\begin{array}{c}0.12 \\
0.5>P>0.2\end{array}$ & $\begin{aligned} & 0.54 \\
&> 0.5 \\
&\end{aligned}$ & $\begin{array}{c}0.92 \\
0.5>P>0.2\end{array}$ \\
\hline $\begin{array}{l}\text { Group } 1 v \\
\text { Group } 3\end{array}$ & $\begin{array}{l}t \\
\mathbf{P}\end{array}$ & $\begin{array}{c}2.47 \\
0.05>P>0.02\end{array}$ & $\begin{array}{r}3.24 \\
<0.01\end{array}$ & $\begin{array}{l}3.89 \\
<0.001\end{array}$ & $\begin{array}{r}4.07 \\
<0.001 \\
\end{array}$ & $\begin{aligned} & 0.18 \\
&> 0.5 \\
&\end{aligned}$ & $\begin{array}{l}0.31 \\
>0.5\end{array}$ \\
\hline $\begin{array}{l}\text { Group } 2 v \\
\text { Group } 3\end{array}$ & $\begin{array}{l}t \\
\mathbf{P}\end{array}$ & $\begin{array}{c}2.60 \\
0.02>P>0.01\end{array}$ & $0.1 \stackrel{1.88}{>}>0.05$ & $\begin{array}{l}4 \cdot 13 \\
<0.001\end{array}$ & $\begin{array}{r}3.05 \\
<0.01\end{array}$ & $\begin{array}{l}0.27 \\
>0.5\end{array}$ & $\begin{array}{l}0.53 \\
>0.5\end{array}$ \\
\hline
\end{tabular}


being 167,263 , and $117 \%$ respectively above the means for the normal group.

\section{DISCUSSION}

The results from normal children agree closely with the figures reported by Engström et al. (1956), the regression equations for FRV, RV, and TLC being very similar. Where growth and age are closely associated during childhood, changes in lung volume compartments correlate well with either height or age. After cessation of growth, the best correlation is obtained when both height and age are used. The age factor presumably becomes important because of the degenerative changes which begin in the lung and thoracic cage. The appropriate regression equations were therefore used to obtain predicted values for the asthmatic subjects.

The departures from normal in the asthmatics were then examined in terms of the classification suggested by Jones (1966). This is based upon objective measurements and avoids all forms of clinical grading. In practice, the slightly labile (group 1) have clinical symptoms which in general are 'mild', whereas the highly labile (group 2) subjects may have mild or severe symptoms. In group 3, with a predominantly fixed increase of airways resistance, symptoms may also be mild or severe. The latter group forms only about $15 \%$ of childhood asthma but a much greater percentage in the adult, the exact figure not being known. The prognosis is more serious because it is in this group that symptoms tend to persist into adult life. The lability index, therefore, is not a direct measure of frequency or severity of attack.

Briscoe (1965) pointed out that the main effect of airways obstruction is to increase the $R V$, and others have reported similarly (Palmer and Diament, 1969 ; Kraepelien et al., 1958). The reports of Lukas (1951), Bates (1952), Beale et al. (1952), and Herschfus et al. (1953) cannot be compared with the present study because observed values were not related to predicted values for lung volume compartments.

In the study reported here the main abnormality is also in the residual volume. In the children from all groups departures from normal were as great as or greater than they were in the adults. It is particularly noteworthy that the increases in group 1 were highly significant and just as great as in group 2. There was, however, a significantly greater increase in group 3 compared with the two labile groups, in both the child and the adult. The findings suggest that persistence over a long period of time of the fixed component of airways resistance, as in group 3 , is the factor which correlates with the biggest increases in RV. More difficult to explain is the degree of abnormality in the clinically mild group 1 subjects with a low level of potential for constriction. This must mean that despite the latter factor there is some degree of persistent decrease of airway calibre accompanied by some compensatory increase of FRC.

The results show that the increase in FRC is present more especially in the child than the adult and, like RV, the FRC is strikingly increased in the group 3 subjects. Although the TLC is significantly increased in all groups, the increase in the labile groups 1 and 2 is of particular interest. It should also be noted that these changes are not manifest in the adult, perhaps reflecting less ability to compensate for changes in airway calibre on account of reduced compliance of lung and thorax.

An important question is whether the lung volume changes in groups 1 and 2 persist into adult life and whether these are accompanied by any change in lability. Blackhall $(1970 \mathrm{a}, \mathrm{b})$ reported a group of 12 subjects who had been free from asthmatic symptoms for 2 to 32 years (mean 10.6 years). Only two had RV values less than the predicted and for the group as a whole the difference between the means for these subjects and a normal control group was significant at the $2 \%$ level. The FRC and TLC were not significantly raised and the lability index ranged from 7 to $28 \%$ with a mean of $16 \cdot 8 \%$. Changes in lung volume and lability may revert towards normal, but, on the other hand, abnormalities in both may persist into adult life long after symptoms of asthma have ceased.

We wish to thank Professor C. A. Clarke for permission to study his patients and for his interest and encouragement in this work; also Mr. F. Meade for statistical assistance and Mrs. S. Dulson for technical assistance.

The work was supported by a Research Fellowship from the Department of Child Health, University of Liverpool and a grant from the Children's Research Fund.

\section{REFERENCES}

Bates, D. V. (1952). Impairment of respiratory function in bronchial asthma. Clin. Sci., 11, 203.

Beale, H. D., Fowler, W. S., and Comroe, J. H. Jr. (1952). Pulmonary function studies in 20 asthmatic patients in the symptom-free interval. J. Allergy, 23, 1. 
Blackhall, M. I. (1970a). The effect of age on ventilatory function in asthma. M.D. thesis, University of Aberdeen.

(1970b). Ventilatory function in subjects with childhood asthma who have become symptom free. Arch. Dis. Childh., 45, 363.

Boren, H. G., Kory, R. C., and Syner, J. C. (1966). The Veterans Administration Army-Co-operative study of pulmonary function. 2. The lung volume and its subdivisions in normal men. Amer. J. Med., 41, 96.

Briscoe, W. A. (1965). Handbook of Physiology, Section 3. Respiration, vol. 2, p. 1366., edited by W. O. Fenn and H. Rahn. American Physiological Society, Washington.

Engström, I., Karlberg, P., and Kraepelien, S. (1956). Respiratory studies in children. 1. Lung volumes in healthy children 6-14 years of age. Acta paediat. (Uppsala), 45, 277.

Gilson, J. C., and Hugh-Jones, P. (1949). The measurement of the total lung volume and breathing capacity. Clin. Sci., 7, 185.
Herschfus, J. S., Bresnick, E., and Segal, M. S. (1953) Pulmonary function studies in bronchial asthma. Control state. Amer. J. Med., 14, 23.

Jones, R. S. (1966). Assessment of respiratory function in the asthmatic child. Brit. med. J., 2, 972.

Kaltreider, N. L., Fray, W. W., and Hyde, H. van Z. (1938) The effect of age on the total pulmonary capacity and its subdivisions. Amer. Rev. Tuberc., 37, 662.

Kraepelien, S., Engström, I., and Karlberg, P. (1958) $\overrightarrow{\vec{C}}$ Respiratory studies in children. Lung volumes im symptom-free asthmatic children 6-14 years of age $\frac{F}{\vec{x}}$ Acta paediat. (Uppsala), 47, 399.

Lukas, D. S. (1951). Pulmonary function in a group oळ్ young patients with bronchial asthma. $J$. Allergy, 22 411.

Needham, C. D., Rogan, M. C., and McDonald, I. (1954) Normal standards for lung volumes, intrapulmonary gas-mixing, and maximum breathing capacity. Thorax 9, 313.

Palmer, K. N. V., and Diament, M. L. (1969). Dynamic anథ static lung volumes and blood-gas tensions in bronchiad asthma. Lancet, 1, 591. 